\title{
DISTRIBUTION OF RADIONUCLIDES IN SURFACE SOIL AND BOTTOM SEDIMENT IN THE DISTRICT OF JESSORE, BANGLADESH AND EVALUATION OF RADIATION HAZARD.
}

\author{
K.A. KABIR ${ }^{1}$, S.M.A. ISLAM ${ }^{1, *}$ AND M. M. RAHMAN ${ }^{2}$ \\ 1 Department of Physics, Jahangirnagar University, Savar, Dhaka, \\ Bangladesh \\ ${ }^{2}$ Health Physics Division, Atomic Energy Center, Post Box No. 164, \\ Dhaka, Bangladesh
}

\begin{abstract}
This paper presents the first reports on the natural and anthropogenic radionuclides in soil and sediment of Jessore, a south-western district of Bangladesh. Surface soil and freshwater sediment were collected from in and around some major water-bodies of this district. To assess the radiological hazard of the natural radioactivity, the radium equivalent activity, the absorbed dose rate, and the external and internal hazard indices were calculated. In the soil and sediment in general, the activity concentration of ${ }^{232} \mathrm{Th}$ was found to be higher than that of ${ }^{226} \mathrm{Ra}$, while that of ${ }^{40} \mathrm{~K}$ markedly exceeds the values of both ${ }^{226} \mathrm{Ra}$ and ${ }^{232} \mathrm{Th}$. The average activities of ${ }^{226} \mathrm{Ra}$ and ${ }^{232} \mathrm{Th}$ in this area were found to be higher than the world average. There was no activity due to fallout $\left({ }^{137} \mathrm{Cs}\right)$ in this area. The radium equivalent activity and the absorbed dose rate due to the natural radionuclides were found to be respectively lower and higher than the world average. The external and internal hazard indices were found to be well below the hazard limit of unity. Our results compare fairly well with other published results.
\end{abstract}

Key-words : Soil, Sediment, Natural lake, Radioactivity, Dose rate

\section{INTRODUCTION}

Naturally occurring primordial radionuclides have been present in the environment since the formation of the earth. Predominant part of the radioactivity of soil and sediment derives from the decay of the primordial radionuclides ${ }^{238} \mathrm{U},{ }^{235} \mathrm{U},{ }^{232} \mathrm{Th},{ }^{87} \mathrm{Rb}$ and ${ }^{40} \mathrm{~K}$ and the numerous decay products of the first three of them. Significant amount of man-made radionuclides ${ }^{137} \mathrm{Cs}$ and ${ }^{90} \mathrm{Sr}$ may also present in the soil and sediment as a result of testing of nuclear weapons in the atmosphere, accidents such as the Chernobyl accident and the routine discharge of radionuclides from nuclear installations. The contribution of other nuclides to the total activity is negligible ${ }^{(1)}$. Once present in the environment, these radionuclides, whether natural or artificial, are available for uptake by plants and animals and so make their way into the food chain.

Because of natural and artificial processes, radionuclides may accumulate and be concentrated in selected areas of the environment. Regional and local variation in the distribution and availability of natural radioactive materials for ingestion and inhalation are related to ancient geological processes and a combination of contemporary geological stress, atmospheric conditions, and intervention by man ${ }^{(2)}$. The natural radioactivity of soil and sediment depends on their formation and transport processes that were involved since soil and sediment formation; chemical and biochemical interactions influence the distribution patterns of Uranium, Thorium and their decay products.

\footnotetext{
${ }^{*}$ Corresponding author
} 
Studies on radiation levels and radionuclides distributions in Jessore have not been carried out so far. The aim of this study was to determine natural $\left({ }^{226} \mathrm{Ra},{ }^{232} \mathrm{Th},{ }^{40} \mathrm{~K}\right)$ and artificial $\left({ }^{137} \mathrm{Cs}\right)$ radioactivity levels in soils and sediments collected from different areas of Jessore. Also, the radium equivalent activity $\left(\mathrm{Ra}_{\mathrm{eq}}\right)$, the absorbed dose rate, and external and internal radiation hazard indices which will be defined later have been calculated and compared with the results in literatures.

\section{EXPERIMENTALS}

\section{Sample collection}

The Jessore district, situated in the south-western region of Bangladesh, was surveyed to collect the soil and sediment samples from different locations of the region. The locations are shown in the Fig.1. Soil sample was collected (at a depth of $0-5 \mathrm{~cm}$.) from the area adjacent to the water-bodies from which sediment sample was collected. The collected soil samples represent the major soil type of the region. All the locations selected for soil sample collection were open, not prone to flooding or other natural disturbances and were not affected by human activities during the recent decades which represent undisturbed soils. All the samples were collected at $5 \mathrm{~cm}$ depth from the soil-surface. Each of the samples was weighed by $500 \mathrm{gm}$. The samples were transported in dried acetone-cleaned polyethylene bags with sample codes.

Bottom sediment samples were collected from 23 different water-bodies (21 baors, one beel and one pond) of the district of Jessore in a period of low water levels during the dry season, January and April 2007. Sediments were taken from the middle of the water bodies so that undisturbed sediment samples could be taken. One sediment sample from each site was taken, each about $1 \mathrm{~kg}$ wet weight placed in polyethylene bags with sample code and transferred to the laboratory.

\section{Sample preparation}

At the lab, the collected samples were transferred from the polyethylene bags to the acetone-cleaned stainless steel bucket and dried in an oven at $100-105^{\circ} \mathrm{C}$ until a constant weight was achieved. Each of the dried samples was grounded to fine powder in an agate motor separately. The powdered soil and sediment samples were then sieved using a fineaperture mesh screen (mesh size $2 \mathrm{~mm}$ ) in order to remove extraneous items like plant materials, roots, pebbles etc. and to obtain a fine-grained sample that would present a uniform matrix to the detector. The grounded samples were stored in separate polyethylene packets as stock samples.

Finally, each of the samples was transferred to cylindrical plastic-container. The containers were approximately of equal size and shape (i.e., diameter $6.5 \mathrm{~cm}$ and height $7.5 \mathrm{~cm}$ ). The net weight of each sample was calculated using a micrometer. The mass of the samples varied because of the varying density of the sample material (Table-1). The containers were then sealed tightly, wrapped with thick vinyl tapes around their screw necks. The samples were stored for at least four weeks to reach secular equilibrium between the ${ }^{238} \mathrm{U}$ and ${ }^{232} \mathrm{Th}$ series and their respective progenies to get ready for measurements ${ }^{(2)}$. 


\section{Measurement procedures}

Measurements were carried out on these samples using a $\gamma$-ray spectrometer comprising p-type co-axial intrinsic HPGe detector of active volume 132 cc supplied by Oxford Instruments Inc. Nuclear Measurement Group (Model No. CPVDS 30-30185 and Serial No. 2604) with relative efficiencies of $30 \%$ and resolution (FWHM) of $1.83 \mathrm{keV}$ for the $1332 \mathrm{keV} \gamma$-ray energy of ${ }^{60} \mathrm{Co}$. The detector was coupled with PC based multichannel analyzer (PCMCA card: TRUMP-PCI-8K) and the gamma-ray spectral analysis was based on a window based software (MAESTRO-32, ver. 5.30 (A65-B32) supplied by the ORTEC, USA) which matched gamma energies at various energy levels to a library of possible isotopes.

Direct determination of ${ }^{226} \mathrm{Ra}$ and ${ }^{232} \mathrm{Th}$ in the samples without any chemical treatment using semiconductor $\gamma$-ray spectrometer is very hard because they do not emit any intensive $\gamma$-rays (lines) of their own. But they have several progenies which have more intensive lines and activities equal to their parents in the state of secular equilibrium. As a result, the measurements of the radionuclides relied on the detecting emissions from their progenies.

The radioactivity concentration of ${ }^{226} \mathrm{Ra}$ was determined from $\gamma$-ray energies of its daughters ${ }^{214} \mathrm{~Pb}(351.92 \& 295.21 \mathrm{keV})$ and ${ }^{214} \mathrm{Bi}(609.31,1120.30 \& 1764.50 \mathrm{keV})$ and the ${ }^{232} \mathrm{Th}$ was determined from $\gamma$-ray energies of its daughters ${ }^{212} \mathrm{~Pb}(238.63 \mathrm{keV}),{ }^{208} \mathrm{Tl}$ $(583.14 \& 510.84 \mathrm{keV})$ and ${ }^{228} \mathrm{Ac}(911.07 \& 969.11 \mathrm{keV})$. The radioactivity concentrations of ${ }^{40} \mathrm{~K}$ and ${ }^{137} \mathrm{Cs}$ were determined from their $\gamma$-ray energy of $1460.80 \mathrm{keV}$ and $662 \mathrm{keV}$ respectively.

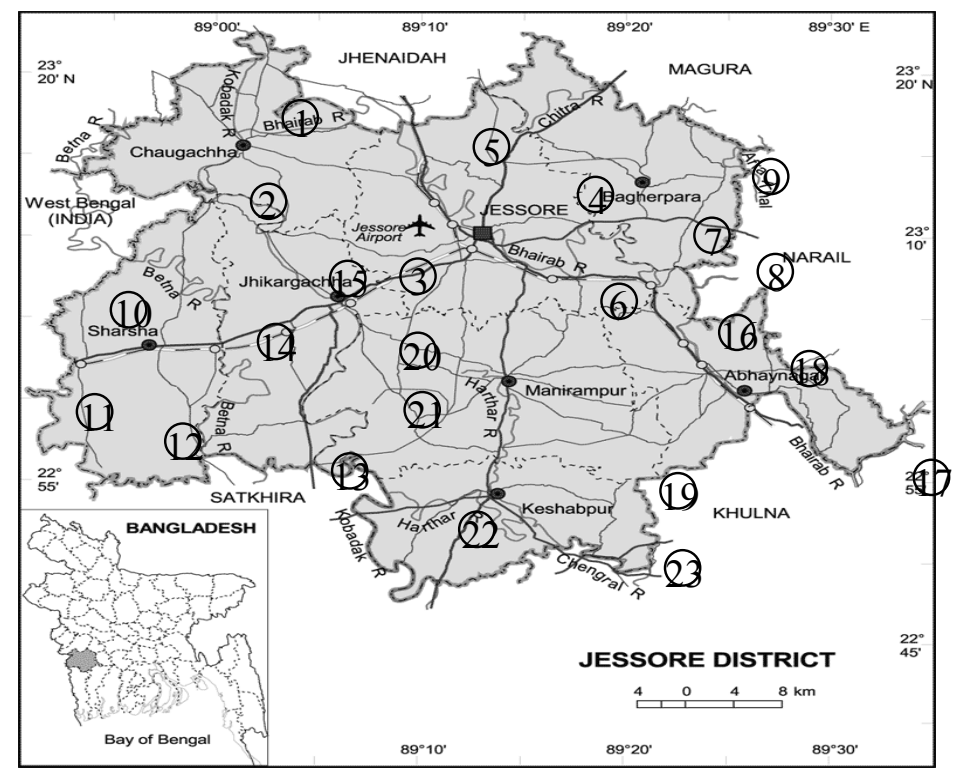

Fig 1. Location of sampling stations. 
Table. 1.

\section{Sites from which surface soil and bottom sediment samples were taken}

\begin{tabular}{clcc} 
Sample & Site & \multicolumn{2}{c}{ Sample weight (g) } \\
& & Marjat Baor, Chaugachha & sediment \\
\hline 1 & & 368.5 & 240.0 \\
2 & Ber-Gobindapur Baor, Chaugachha & 331.8 & 334.7 \\
3 & Bookbhara Baor, Jessore Sadar & 389.3 & 379.0 \\
4 & Ghurulia Baor, Jessore Sadar & 323.5 & 312.2 \\
5 & Laukhali Baor, Jessore Sadar & 361.0 & 284.0 \\
6 & Khanika picnic-spot pond, Jessore Sadar & 362.0 & 358.0 \\
7 & Habullae Baor, Bagharpara & 341.3 & 266.2 \\
8 & Radhanagar Baor, Bagharpara & 408.0 & 329.5 \\
9 & Manikdi Baor, Bagharpara & 305.0 & 308.0 \\
10 & Bahadurpur Baor, Sharsha & 377.0 & 361.5 \\
11 & Rajagonj Baor, Sharsha & 391.0 & 305.8 \\
12 & Mohishakura Baor, Sharsha & 394.0 & 313.0 \\
13 & Ujjajpur Baor,Jhikargachha & 351.3 & 346.0 \\
14 & Srirampur Baor, Jhikargachha & 382.0 & 287.5 \\
15 & Bodkhan Baor, Jhikargachha & 346.0 & 343.0 \\
16 & Prembag Baor, Abhainagar & 367.8 & 237.0 \\
17 & Nawli Beel, Abhainagar & 313.0 & 300.0 \\
18 & Purakhali Baor, Abhainagar & 270.0 & 269.5 \\
19 & Nehalpur Beel, Monirampur & 370.8 & 251.8 \\
20 & Hariharnagar Baor, Monirampur & 333.0 & 285.0 \\
21 & Khedapara Baor, Monirampur & 357.0 & 308.5 \\
23 & Mosina Baor, Keshabpur & 346.4 & 297.0 \\
& Garalia Beel, Keshabpur & 303.0 & 314.0
\end{tabular}

The efficiency calibration of the detector was performed by using mixed standard sources

${ }^{133} \mathrm{Ba}$ and ${ }^{137} \mathrm{Cs}$ supplied by the Amersham International, England, sample code no. QCY B41 mixed with $400 \mathrm{~g}$ of analar grade $\mathrm{Al}_{2} \mathrm{O}_{3}$ so as to make composite reference sources comprising of various gamma energies in a simulated crushed sample matrix. Each sample was counted for $5000 \mathrm{sec}$. Prior of sample counting, two background counts were normally taken twice during week ends for $5000 \mathrm{sec}$ each and on average of this background was then subtracted from the samples counted during that week.

\section{Theoretical calculations}

The activity concentrations

The activity concentrations of the radionuclides in the measured samples were computed using the following relation ${ }^{(3)}$,

$$
A_{s}\left(B q K g^{-1}\right)=\frac{C_{a}}{\varepsilon P_{\gamma} M_{s}}
$$

where $\mathrm{C}_{\mathrm{a}}$ is the net gamma counting rate (counts per second), $\varepsilon$ the detector efficiency of the specific $\gamma$-ray, $P_{\gamma}$ the transition probability of gamma decay and $M_{s}$ is the mass of the sample (kg). 


\section{$\underline{\text { Radium equivalent activity }}$}

For the purpose of comparing the radiological effect or activity of materials that contain ${ }^{226} \mathrm{Ra},{ }^{232} \mathrm{Th}$ and ${ }^{40} \mathrm{~K}$ by a single quantity, which takes into account the radiation hazards associated with them, a common index termed the radium equivalent activity $\left(\mathrm{Ra}_{\mathrm{eq}}\right)$ is used. This activity index provides a useful guideline in regulating the safety standards on radiation protection for the general public residing in the area under investigation. The $\mathrm{Ra}_{\mathrm{eq}}$ index represents a weighted sum of activities of the above mentioned natural radionuclides and is based on the estimation that $1 \mathrm{Bqkg}^{-1}$ of ${ }^{226} \mathrm{Ra}^{2} 0.7 \mathrm{Bqkg}^{-1}$ of ${ }^{232} \mathrm{Th}$, and $13 \mathrm{Bqkg}^{-1}$ of ${ }^{40} \mathrm{~K}$ produce the same gamma radiation dose rates. The index is given as ${ }^{(4)}$ :

$$
R a_{e q}=A_{R a}+1.43 A_{T h}+0.077 A_{K}
$$

where $A_{R a}, A_{T h}$ and $A_{k}$ are the average activity concentration in the sample in $\mathrm{Bqkg}^{-1}$ of ${ }^{226} \mathrm{Ra},{ }^{232} \mathrm{Th}$, and ${ }^{40} \mathrm{~K}$ respectively.

\section{The absorbed dose rate}

The absorbed dose rate in air at average gonad height of one meter above the surface of ground due to the natural radionuclides ${ }^{226} \mathrm{Ra},{ }^{232} \mathrm{Th}$ and ${ }^{40} \mathrm{~K}$ was estimated using formula given in UNSCEAR, $1988^{(4)}$ as under :

$$
D=\left[0.427 A_{R a}+0.662 A_{T h}+0.0432 A_{K}\right] n G y h^{-1}
$$

where $A_{R a}, A_{T h}$ and $A_{k}$ have the same meaning as in Equation 2.

\section{External and Internal Hazard indices}

The soils and sediments are used for making earthen huts, bricks and pottery materials and, hence, the external radiation hazard index, $\mathrm{H}_{\mathrm{ex}}$ and internal radiation hazard index, $\mathrm{H}_{\text {in }}$ were calculated using the following relations ${ }^{(2)}$.

$$
\begin{gathered}
H_{e x}=\frac{A_{R a}}{370}+\frac{A_{T h}}{259}+\frac{A_{K}}{4810} \leq 1 \\
H_{\text {in }}=\frac{A_{R a}}{185}+\frac{A_{T h}}{259}+\frac{A_{K}}{4810}
\end{gathered}
$$

where $A_{R a}, A_{T h}$ and $A_{k}$ have the same meaning as in Equation 2. 
Table. 2.

Radioactivity concentrations of radionuclides as well as the calculated Ra equivalent activity, absorbed dose rate, external hazard index and internal hazard index in soil and sediment samples across the district of Jessore.

\begin{tabular}{|c|c|c|c|c|c|c|c|c|c|}
\hline \multirow{2}{*}{$\begin{array}{r}\text { Sam. } \\
\text { No }\end{array}$} & \multirow{2}{*}{$\begin{array}{c}\text { Types } \\
\text { of } \\
\text { sample }\end{array}$} & \multicolumn{4}{|c|}{ Activity concentration( $\left.\mathrm{Bqkg}^{-1}\right)$} & \multirow{2}{*}{$\begin{array}{c}\mathbf{R a}_{\mathrm{eq}} \\
\left(\mathrm{Bqkg}^{-1}\right)\end{array}$} & \multirow{2}{*}{$\begin{array}{rr}D & \text { Dose Rate } \\
& \left(\mathrm{nGyh}^{-1}\right)\end{array}$} & \multirow[t]{2}{*}{$\mathbf{H}_{\mathrm{ex}}$} & \multirow[t]{2}{*}{$\mathbf{H}_{\mathrm{i}}$} \\
\hline & & ${ }^{226} \mathrm{Ra}$ & ${ }^{232} \mathrm{Th}$ & ${ }^{40} \mathrm{~K}$ & ${ }^{137} \mathrm{Cs}$ & & & & \\
\hline 1 & $\begin{array}{c}\text { soil } \\
\text { sediment }\end{array}$ & $\begin{array}{c}43 \pm 2 \\
\mathbf{2 3} \pm \mathbf{2}\end{array}$ & $\begin{array}{c}54 \pm 3 \\
\mathbf{2 0} \pm \mathbf{5}\end{array}$ & $\begin{array}{c}413 \pm 32 \\
\mathbf{2 5 4} \pm \mathbf{4 3}\end{array}$ & - & $\begin{array}{l}152 \pm 9 \\
\mathbf{7 1} \pm \mathbf{1 2}\end{array}$ & $\begin{array}{l}72 \pm 4 \\
34 \pm 6\end{array}$ & $\begin{array}{l}0.41 \pm 0.02 \\
0.19 \pm \mathbf{0 . 0 3}\end{array}$ & $\begin{array}{l}0.53 \pm 0.03 \\
\mathbf{0 . 2 5} \pm \mathbf{0 . 0 4}\end{array}$ \\
\hline 2 & $\begin{array}{c}\text { soil } \\
\text { sediment }\end{array}$ & $\begin{array}{c}46 \pm 2 \\
25 \pm 2\end{array}$ & $\begin{array}{l}43 \pm 4 \\
36 \pm 3\end{array}$ & $\begin{array}{c}487 \pm 36 \\
391 \pm 56\end{array}$ & - & $\begin{array}{l}145 \pm 10 \\
107 \pm 11\end{array}$ & $\begin{array}{l}69 \pm 5 \\
51 \pm 5\end{array}$ & $\begin{array}{l}0.39 \pm 0.03 \\
0.29 \pm 0.03\end{array}$ & $\begin{array}{l}0.52 \pm 0.03 \\
0.36 \pm 0.03\end{array}$ \\
\hline 3 & $\begin{array}{c}\text { soil } \\
\text { sediment }\end{array}$ & $\begin{array}{l}56 \pm 2 \\
41 \pm 2\end{array}$ & $\begin{array}{l}63 \pm 4 \\
45 \pm 5\end{array}$ & $\begin{array}{l}424 \pm 31 \\
426 \pm 31\end{array}$ & - & $\begin{array}{l}179 \pm 12 \\
138 \pm 12\end{array}$ & $\begin{array}{l}84 \pm 5 \\
66 \pm 6\end{array}$ & $\begin{array}{l}0.48 \pm 0.03 \\
0.37 \pm 0.03\end{array}$ & $\begin{array}{l}0.63 \pm 0.03 \\
0.48 \pm 0.04\end{array}$ \\
\hline 4 & $\begin{array}{c}\text { soil } \\
\text { sediment }\end{array}$ & $\begin{array}{l}47 \pm 2 \\
44 \pm 2\end{array}$ & $\begin{array}{l}52 \pm 4 \\
43 \pm 8\end{array}$ & $\begin{array}{c}542 \pm 37 \\
470 \pm 38\end{array}$ & - & $\begin{array}{l}163 \pm 11 \\
142 \pm 16\end{array}$ & $\begin{array}{l}78 \pm 5 \\
68 \pm 8\end{array}$ & $\begin{array}{l}0.44 \pm 0.03 \\
0.38 \pm 0.04\end{array}$ & $\begin{array}{l}0.57 \pm 0.03 \\
0.50 \pm 0.05\end{array}$ \\
\hline 5 & $\begin{array}{c}\text { soil } \\
\text { sediment }\end{array}$ & $\begin{array}{l}51 \pm 2 \\
56 \pm 2\end{array}$ & $\begin{array}{c}64 \pm 4 \\
57 \pm 18\end{array}$ & $\begin{array}{c}441 \pm 33 \\
548 \pm 42\end{array}$ & - & $\begin{array}{r}177 \pm 10 \\
180 \pm 31\end{array}$ & $\begin{array}{c}83 \pm 5 \\
85 \pm 15\end{array}$ & $\begin{array}{l}0.48 \pm 0.03 \\
0.49 \pm 0.08\end{array}$ & $\begin{array}{l}0.61 \pm 0.03 \\
0.64 \pm 0.09\end{array}$ \\
\hline 6 & $\begin{array}{c}\text { soil } \\
\text { sediment }\end{array}$ & $\begin{array}{c}49 \pm 2 \\
42 \pm 2\end{array}$ & $\begin{array}{l}58 \pm 4 \\
32 \pm 12\end{array}$ & $\begin{array}{l}464 \pm 32 \\
422 \pm 33\end{array}$ & - & $\begin{array}{c}168 \pm 10 \\
120 \pm 22\end{array}$ & $\begin{array}{c}79 \pm 5 \\
57 \pm 10\end{array}$ & $\begin{array}{l}0.45 \pm 0.03 \\
0.25 \pm 0.06\end{array}$ & $\begin{array}{l}0.59 \pm 0.03 \\
0.44 \pm 0.06\end{array}$ \\
\hline 7 & $\begin{array}{c}\text { soil } \\
\text { sediment }\end{array}$ & $\begin{array}{c}44 \pm 2 \\
35 \pm 2\end{array}$ & $\begin{array}{l}48 \pm 4 \\
37 \pm 18\end{array}$ & $\begin{array}{c}424 \pm 34 \\
411 \pm 42\end{array}$ & - & $\begin{array}{l}145 \pm 10 \\
120 \pm 31\end{array}$ & $\begin{array}{c}69 \pm 5 \\
57 \pm 15\end{array}$ & $\begin{array}{l}0.39 \pm 0.03 \\
0.32 \pm 0.08\end{array}$ & $\begin{array}{l}0.51 \pm 0.03 \\
0.42 \pm 0.09\end{array}$ \\
\hline 8 & $\begin{array}{c}\text { soil } \\
\text { sediment }\end{array}$ & $\begin{array}{l}47 \pm 2 \\
35 \pm 2\end{array}$ & $\begin{array}{l}53 \pm 4 \\
47 \pm 4\end{array}$ & $\begin{array}{c}428 \pm 29 \\
410 \pm 35\end{array}$ & - & $\begin{array}{l}156 \pm 10 \\
134 \pm 10\end{array}$ & $\begin{array}{l}74 \pm 5 \\
64 \pm 5\end{array}$ & $\begin{array}{l}0.42 \pm 0.03 \\
0.36 \pm 0.03\end{array}$ & $\begin{array}{l}0.55 \pm 0.03 \\
0.46 \pm 0.03\end{array}$ \\
\hline 9 & $\begin{array}{c}\text { soil } \\
\text { sediment }\end{array}$ & $\begin{array}{c}55 \pm 2 \\
61 \pm 2\end{array}$ & $\begin{array}{c}53 \pm 4 \\
85 \pm 7\end{array}$ & $\begin{array}{c}611 \pm 40 \\
\mathbf{9 8 6} \pm \mathbf{4 3}\end{array}$ & - & $\begin{array}{l}178 \pm 11 \\
\mathbf{2 5 9} \pm \mathbf{1 5}\end{array}$ & $\begin{array}{c}85 \pm 5 \\
125 \pm 7\end{array}$ & $\begin{array}{l}0.48 \pm 0.03 \\
\mathbf{0 . 7 0} \pm \mathbf{0 . 0 4}\end{array}$ & $\begin{array}{l}0.63 \pm 0.03 \\
\mathbf{0 . 8 6} \pm \mathbf{0 . 0 5}\end{array}$ \\
\hline 10 & $\begin{array}{c}\text { soil } \\
\text { sediment }\end{array}$ & $\begin{array}{c}44 \pm 2 \\
39 \pm 2\end{array}$ & $\begin{array}{l}33 \pm 6 \\
34 \pm 11\end{array}$ & $\begin{array}{c}500 \pm 51 \\
405 \pm 52\end{array}$ & - & $\begin{array}{l}\mathbf{1 3 0} \pm \mathbf{1 5} \\
119 \pm 22\end{array}$ & $\begin{array}{c}62 \pm 7 \\
57 \pm 10\end{array}$ & $\begin{array}{l}\mathbf{0 . 3 5} \pm \mathbf{0 . 0 4} \\
0.32 \pm 0.06\end{array}$ & $\begin{array}{l}0.47 \pm 0.04 \\
0.43 \pm 0.06\end{array}$ \\
\hline 11 & $\begin{array}{c}\text { soil } \\
\text { sediment }\end{array}$ & $\begin{array}{c}47 \pm 2 \\
55 \pm 2\end{array}$ & $\begin{array}{c}53 \pm 4 \\
39 \pm 7\end{array}$ & $\begin{array}{c}424 \pm 31 \\
497 \pm 39\end{array}$ & - & $\begin{array}{l}155 \pm 10 \\
149 \pm 15\end{array}$ & $\begin{array}{l}73 \pm 5 \\
71 \pm 7\end{array}$ & $\begin{array}{l}0.42 \pm 0.03 \\
0.40 \pm 0.04\end{array}$ & $\begin{array}{l}0.55 \pm 0.03 \\
0.55 \pm 0.05\end{array}$ \\
\hline 12 & $\begin{array}{c}\text { soil } \\
\text { sediment }\end{array}$ & $\begin{array}{c}55 \pm 2 \\
49 \pm 2\end{array}$ & $\begin{array}{l}70 \pm 4 \\
65 \pm 16\end{array}$ & $\begin{array}{c}\mathbf{3 4 5} \pm \mathbf{2 9} \\
597 \pm 39\end{array}$ & - & $\begin{array}{l}182 \pm 10 \\
188 \pm 28\end{array}$ & $\begin{array}{c}85 \pm 5 \\
90 \pm 13\end{array}$ & $\begin{array}{l}0.49 \pm 0.03 \\
0.51 \pm 0.07\end{array}$ & $\begin{array}{l}0.64 \pm 0.03 \\
0.64 \pm 0.08\end{array}$ \\
\hline 13 & $\begin{array}{c}\text { soil } \\
\text { sediment }\end{array}$ & $\begin{array}{l}50 \pm 2 \\
36 \pm 2\end{array}$ & $\begin{array}{c}46 \pm 4 \\
43 \pm 5\end{array}$ & $\begin{array}{c}397 \pm 33 \\
393 \pm 33\end{array}$ & - & $\begin{array}{l}146 \pm 10 \\
128 \pm 12\end{array}$ & $\begin{array}{l}69 \pm 5 \\
61 \pm 6\end{array}$ & $\begin{array}{l}0.40 \pm 0.03 \\
0.35 \pm 0.03\end{array}$ & $\begin{array}{l}0.53 \pm 0.03 \\
0.44 \pm 0.04\end{array}$ \\
\hline 14 & $\begin{array}{c}\text { soil } \\
\text { sediment }\end{array}$ & $\begin{array}{l}44 \pm 2 \\
32 \pm 2\end{array}$ & $\begin{array}{l}55 \pm 4 \\
49 \pm 10\end{array}$ & $\begin{array}{c}438 \pm 31 \\
666 \pm 42\end{array}$ & - & $\begin{array}{l}156 \pm 10 \\
153 \pm 19\end{array}$ & $\begin{array}{l}74 \pm 5 \\
75 \pm 9\end{array}$ & $\begin{array}{l}0.42 \pm 0.03 \\
0.41 \pm 0.05\end{array}$ & $\begin{array}{l}0.54 \pm 0.03 \\
0.50 \pm 0.06\end{array}$ \\
\hline 15 & $\begin{array}{c}\text { soil } \\
\text { sediment }\end{array}$ & $\begin{array}{l}61 \pm 2 \\
32 \pm 2\end{array}$ & $\begin{array}{l}56 \pm 4 \\
57 \pm 15\end{array}$ & $\begin{array}{c}495 \pm 35 \\
458 \pm 34\end{array}$ & - & $\begin{array}{l}179 \pm 10 \\
149 \pm 26\end{array}$ & $\begin{array}{c}84 \pm 5 \\
71 \pm 12\end{array}$ & $\begin{array}{l}0.48 \pm 0.03 \\
0.40 \pm 0.07\end{array}$ & $\begin{array}{l}0.65 \pm 0.03 \\
0.49 \pm 0.08\end{array}$ \\
\hline 16 & $\begin{array}{c}\text { soil } \\
\text { sediment }\end{array}$ & $\begin{array}{c}52 \pm 2 \\
36 \pm 2\end{array}$ & $\begin{array}{c}49 \pm 3 \\
55 \pm 9\end{array}$ & $\begin{array}{c}392 \pm 32 \\
513 \pm 48\end{array}$ & - & $\begin{array}{c}152 \pm 9 \\
154 \pm 19\end{array}$ & $\begin{array}{l}72 \pm 4 \\
74 \pm 9\end{array}$ & $\begin{array}{l}0.41 \pm 0.02 \\
0.42 \pm 0.05\end{array}$ & $\begin{array}{l}0.55 \pm 0.03 \\
0.51 \pm 0.06\end{array}$ \\
\hline 17 & $\begin{array}{c}\text { soil } \\
\text { sediment }\end{array}$ & $\begin{array}{l}65 \pm 2 \\
50 \pm 2\end{array}$ & $\begin{array}{c}56 \pm 4 \\
63 \pm 2\end{array}$ & $\begin{array}{c}614 \pm 38 \\
701 \pm 40\end{array}$ & - & $\begin{array}{c}192 \pm 11 \\
194 \pm 8\end{array}$ & $\begin{array}{l}91 \pm 8 \\
93 \pm 4\end{array}$ & $\begin{array}{l}0.52 \pm 0.03 \\
0.52 \pm 0.02\end{array}$ & $\begin{array}{l}0.70 \pm 0.03 \\
0.66 \pm 0.03\end{array}$ \\
\hline 18 & $\begin{array}{c}\text { soil } \\
\text { sediment }\end{array}$ & $\begin{array}{l}\mathbf{6 7} \pm \mathbf{2} \\
37 \pm 2\end{array}$ & $\begin{array}{c}64 \pm 5 \\
38 \pm 9\end{array}$ & $\begin{array}{c}\mathbf{6 7 4} \pm \mathbf{4 5} \\
457 \pm 43\end{array}$ & - & $\begin{array}{l}\mathbf{2 1 0} \pm \mathbf{1 3} \\
126 \pm 18\end{array}$ & $\begin{array}{c}100 \pm 6 \\
61 \pm 7\end{array}$ & $\begin{array}{l}\mathbf{0 . 5 7} \pm \mathbf{0 . 0 3} \\
0.34 \pm 0.05\end{array}$ & $\begin{array}{l}\mathbf{0 . 7 5} \pm \mathbf{0 . 0 4} \\
0.44 \pm 0.05\end{array}$ \\
\hline 19 & $\begin{array}{c}\text { soil } \\
\text { sediment }\end{array}$ & $\begin{array}{c}\mathbf{2 8} \pm \mathbf{2} \\
58 \pm 3\end{array}$ & $\begin{array}{l}45 \pm 6 \\
50 \pm 19\end{array}$ & $\begin{array}{l}514 \pm 52 \\
515 \pm 45\end{array}$ & - & $\begin{array}{l}132 \pm 15 \\
169 \pm 34\end{array}$ & $\begin{array}{c}64 \pm 7 \\
80 \pm 16\end{array}$ & $\begin{array}{l}0.36 \pm 0.04 \\
0.46 \pm 0.09\end{array}$ & $\begin{array}{l}\mathbf{0 . 4 3} \pm \mathbf{0 . 0 4} \\
0.61 \pm 0.10\end{array}$ \\
\hline 20 & $\begin{array}{c}\text { soil } \\
\text { sediment }\end{array}$ & $\begin{array}{c}47 \pm 2 \\
47 \pm 2\end{array}$ & $\begin{array}{l}50 \pm 4 \\
42 \pm 14\end{array}$ & $\begin{array}{c}481 \pm 36 \\
389 \pm 39\end{array}$ & - & $\begin{array}{l}156 \pm 10 \\
137 \pm 25\end{array}$ & $\begin{array}{c}74 \pm 5 \\
65 \pm 12\end{array}$ & $\begin{array}{l}0.42 \pm 0.03 \\
0.37 \pm 0.07\end{array}$ & $\begin{array}{l}0.55 \pm 0.03 \\
0.50 \pm 0.07\end{array}$ \\
\hline 21 & $\begin{array}{c}\text { soil } \\
\text { sediment }\end{array}$ & $\begin{array}{c}45 \pm 2 \\
53 \pm 2\end{array}$ & $\begin{array}{l}70 \pm 4 \\
68 \pm 11\end{array}$ & $\begin{array}{c}489 \pm 33 \\
493 \pm 37\end{array}$ & - & $\begin{array}{l}183 \pm 10 \\
188 \pm 21\end{array}$ & $\begin{array}{c}87 \pm 5 \\
89 \pm 10\end{array}$ & $\begin{array}{l}0.49 \pm 0.03 \\
0.51 \pm 0.06\end{array}$ & $\begin{array}{l}0.62 \pm 0.03 \\
0.65 \pm 0.06\end{array}$ \\
\hline 22 & $\begin{array}{c}\text { soil } \\
\text { sediment }\end{array}$ & $\begin{array}{l}36 \pm 2 \\
41 \pm 2\end{array}$ & $\begin{array}{c}45 \pm 6 \\
40 \pm 9\end{array}$ & $\begin{array}{c}556 \pm 58 \\
531 \pm 40\end{array}$ & - & $\begin{array}{l}143 \pm 15 \\
139 \pm 18\end{array}$ & $\begin{array}{l}69 \pm 7 \\
67 \pm 9\end{array}$ & $\begin{array}{l}0.39 \pm 0.04 \\
0.38 \pm 0.05\end{array}$ & $\begin{array}{l}0.48 \pm 0.04 \\
0.49 \pm 0.05\end{array}$ \\
\hline 23 & soil & $30 \pm 2$ & $48 \pm 3$ & $518 \pm 39$ & - & $139 \pm 9$ & $67 \pm 4$ & $0.37 \pm 0.03$ & $0.46 \pm 0.03$ \\
\hline
\end{tabular}




\begin{tabular}{|c|c|c|c|c|c|c|c|c|c|}
\hline & sediment & $62 \pm 2$ & $55 \pm 8$ & $629 \pm 39$ & - & $189 \pm 16$ & $90 \pm 8$ & $0.51 \pm 0.04$ & $0.68 \pm 0.05$ \\
\hline $\begin{array}{l}\text { Aver- } \\
\text { age }\end{array}$ & soil & $48 \pm 9$ & $53 \pm 9$ & $481 \pm 78$ & - & $161 \pm 20$ & $77 \pm 9$ & $0.44 \pm 0.05$ & $0.57 \pm 0.07$ \\
\hline $\pm 1 \sigma$ & sediment & $43 \pm 11$ & $48 \pm 14$ & $503 \pm 143$ & - & $150 \pm 37$ & $72 \pm 18$ & $0.40 \pm 0.10$ & $0.52 \pm 0.13$ \\
\hline
\end{tabular}

( \pm values represent counting error for individual measurement and standard deviation for average. The maximum and minimum values are given in bold face) 


\section{RESULTS AND DISCUSSION}

Table- 2 presents the calculated activity concentrations of radionuclides obtained from gamma spectrometry measurements for 23 soil and 23 sediment samples collected from different areas of the district of Jessore, Bangladesh. Also shown are the derived radium equivalent activity, the absorbed dose rate, and external and internal radiation hazard indices due to activity concentration of the natural radionuclides measured. Three major natural gamma radiation sources were identified. Radium-226 was the precursor of most of the $\gamma$-emitting radionuclide identified in the $U$ decay series. Thorium-232 was the likely precursor of the isotopes identified in the Th decay series. Potassium- 40 which accounted for most of the activity being the third source ${ }^{(5)}$.

Although it is unlikely that two samples from different locations have similar radioactivity yet the values found in this work are comparable to the results reported by others. It should be noted that the values given in the Table-3 and Table-4 are not the representative values for the respective countries but for the locations from where the samples have been collected.

For ${ }^{226}$ Ra activity concentration, each value was obtained from the $351.92 \mathrm{keV}$ photo-peaks of ${ }^{214} \mathrm{~Pb}$. The results for soil ranged from $28 \pm 2$ to $67 \pm 2 \mathrm{Bqkg}^{-1}$ with an average of $48 \pm 9 \mathrm{Bqkg}^{-1}$ and that for sediment ranged from $23 \pm 2$ to $62 \pm 2$ with an average of $43 \pm 11 \mathrm{Bqkg}^{-1}$. For the ${ }^{232} \mathbf{T h}$ activity concentration, each value was an average of three values obtained from $238.63 \mathrm{keV}$ photo-peaks of ${ }^{212} \mathrm{~Pb}, 911.07$ and $969.11 \mathrm{keV}$ photopeaks of ${ }^{228} \mathrm{Ac}$. The results for soil ranged from $33 \pm 6$ to $70 \pm 4 \mathrm{Bqkg}^{-1}$ with an average of $53 \pm 9 \mathrm{Bqkg}^{-1}$ and that for sediment ranged from $20 \pm 5$ to $85 \pm 7$ with an average of $48 \pm 14$ $\mathrm{Bqkg}^{-1}$. The activity concentration of ${ }^{40} \mathbf{K}$ was obtained from its photo-peak of 1460.80 $\mathrm{keV}$. The results for soil ranged from $345 \pm 29$ to $674 \pm 45 \mathrm{Bqkg}^{-1}$ with the average value of $481 \pm 78 \mathrm{Bqkg}^{-1}$ and that for sediment ranged from $254 \pm 43$ to $986 \pm 43$ with an average of $503 \pm 143 \mathrm{Bqkg}^{-1}$. The errors quoted represent the counting error for individual measurements and standard deviation for means.

Fig. 2 - 5 show that the activity concentration of thorium is higher than radium, which is evident from the fact that thorium is 1.5 times higher than that of Uranium in earth's crust[13]. It is also observed that the measured activity concentration of ${ }^{40} \mathrm{~K}$ exceeds markedly the values of both Radium and Thorium, as it is the most abundant radioactive element under consideration. Moreover the excessive use of the Potassium containing fertilizers in the area adjacent to the sampling sites may contribute to the higher values of ${ }^{40} \mathrm{~K}$ activity. In the present study, activity concentrations of ${ }^{226} \mathrm{Ra}$ and ${ }^{232} \mathrm{Th}$ in soil and sediment are comparable with the reported values in Table-3, especially with the different regions of Bangladesh ${ }^{(6-9,17)}$. The activity concentrations of ${ }^{40} \mathrm{~K}$ are comparable with the other values reported in Table 3. Moreover, our obtained values fall within the range of corresponding world values and other published results mentioned in Table-3. The world average activity concentration of ${ }^{226} \mathrm{Ra}$ is $40 \mathrm{Bqkg}^{-1}$ with ranges of $15-50 \mathrm{Bqkg}^{-1}$,

${ }^{232} \mathrm{Th}$ is $40 \mathrm{Bqkg}^{-1}$ with ranges of $7-50 \mathrm{Bqkg}^{-1}$ and ${ }^{40} \mathrm{~K}$ is $580 \mathrm{Bqkg}^{-1}$ with ranges of $100-700 \mathrm{Bqkg}^{-1(1,4)}$.

\section{The fission product $\left({ }^{137} \mathrm{Cs}\right)$}

The manmade fission product residue ${ }^{137} \mathrm{Cs}$, which would come down to this part of the earth from the atmosphere following the nuclear power plant accident at Chernobyl on 
26 April 1986 and other previous test of nuclear devices around the world, was considered in this study to obtain an estimate of fallout in Jessore. But no detectable activity of ${ }^{137} \mathrm{Cs}$ was observed in the soil and sediment samples under study. It implies, therefore, that there is no activity due to fallout in the area of the district of Jessore.

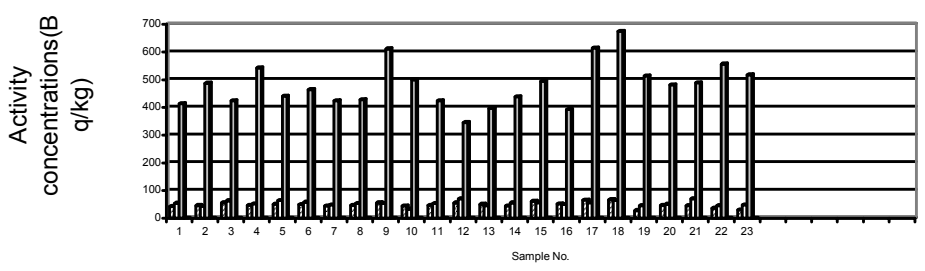

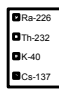

Fig. 2. Activity concentrations in the soil samples $(\mathrm{Bq} / \mathrm{kg})$

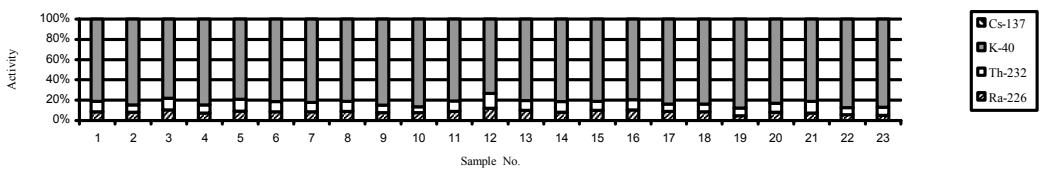

Fig. 3. Fractional contribution of the radionuclides present in our soli samples

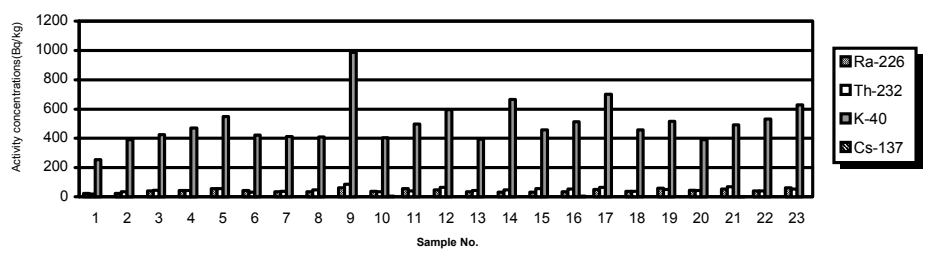

Fig. 4. Activity concentrations in the sediment samples $(\mathrm{Bq} / \mathrm{kg})$

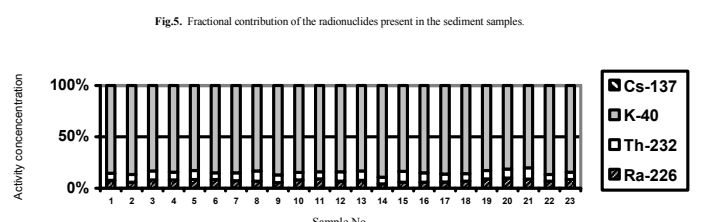

Fig. 5. Fractional contribution of the radionuclides present in the sediment samples (Bz/kg) 
Table. 3 .

Comparison of Radioactivity Level of the Soil and sediment Samples of Different Countries with that of the Present Work

\begin{tabular}{|c|c|c|c|c|c|}
\hline \multirow[t]{2}{*}{ Country } & \multirow{2}{*}{$\begin{array}{l}\text { Type of } \\
\text { Sample }\end{array}$} & \multicolumn{4}{|c|}{ Activity in $\mathrm{Bqkg}^{-1}$} \\
\hline & & ${ }^{226} \mathrm{Ra}$ & ${ }^{232} \mathrm{Th}$ & ${ }^{40} \mathrm{~K}$ & ${ }^{137} \mathrm{Cs}$ \\
\hline $\begin{array}{c}\text { Chittagong } \\
\text { (Bangladesh) }^{(6)}\end{array}$ & Soil & 34.6 & 60 & 438 & 1.08 \\
\hline $\begin{array}{c}\text { Pabna } \\
(\text { Bangladesh })^{(7)}\end{array}$ & Soil & 33 & 47 & 449 & 4 \\
\hline $\begin{array}{c}\text { Dhaka } \\
\text { (Bangladesh) }^{(8)}\end{array}$ & Soil & 33 & 55 & 574 & 7 \\
\hline $\begin{array}{l}\text { Nine southern districts } \\
(\text { Bangladesh })^{(9)}\end{array}$ & soil & 42 & 81 & 833 & 2.08 \\
\hline 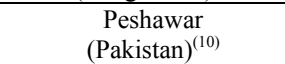 & $\begin{array}{c}\text { Soil } \\
\text { (brick) }\end{array}$ & 65 & 84 & 646 & - \\
\hline Louisiana (USA) $^{(5)}$ & Soil & $43-95$ & $50-190$ & $43-729$ & $5-58$ \\
\hline Zacatecas (Mexico) $)^{(3)}$ & Soil & 23 & 19 & 530 & - \\
\hline All India average ${ }^{(11)}$ & Soil & 31 & 63 & 394 & - \\
\hline $\begin{array}{c}\text { Jessore (Bangladesh) } \\
\text { [Present study] }\end{array}$ & Soil & $\begin{array}{c}48.32 \\
(28-67) \\
\end{array}$ & $\begin{array}{c}53.34 \\
(33-70) \\
\end{array}$ & $\begin{array}{c}481.35 \\
(345-674) \\
\end{array}$ & - \\
\hline Worldwide average $^{(1)}$ & & $40(15-50)$ & $40(7-50)$ & $\begin{array}{l}580(100- \\
700)\end{array}$ & - \\
\hline $\begin{array}{l}\text { Vojvodina(Serbia and } \\
\text { Montenegro })^{(12)}\end{array}$ & Sediment & 30 & 49 & 520 & 45 \\
\hline Danube $^{(13)}$ & Sediment & 32 & 36 & 445 & 28 \\
\hline USA(Louisiana) $)^{(5)}$ & Sediment & $45-69$ & $10-17$ & $276-686$ & $1-43$ \\
\hline Lake Nasser(Egypt) $^{(14)}$ & Sediment & $21(4-48)$ & $23(8-50)$ & $155(16-487)$ & - \\
\hline Grliska Lake(Serbia) $^{(15)}$ & Sediment & $7.9-12.2$ & $18-31.3$ & $271-456$ & $\begin{array}{l}14.5- \\
31.9\end{array}$ \\
\hline French $^{(16)}$ & sediment & $9-62$ & $16-55$ & $120-1026$ & - \\
\hline \multirow[t]{2}{*}{$\begin{array}{c}\text { Chittagong } \\
\text { (Bangladesh) }^{(6)}\end{array}$} & $\begin{array}{c}\text { Sediment(Ka } \\
\text { rnaph-uli } \\
\text { river })\end{array}$ & $35.9(18.4-85.2)$ & $65.5(50.8-88.4)$ & $\begin{array}{l}272(217- \\
320)\end{array}$ & $\begin{array}{c}2.2 \\
(1.68- \\
2.7)\end{array}$ \\
\hline & $\begin{array}{l}\text { Sediment(Sh } \\
\text { ango river) }\end{array}$ & $27.8(24-31.9)$ & $57.5(52.4-61.7)$ & $\begin{array}{l}255(212- \\
292)\end{array}$ & $\begin{array}{c}2.1 \\
(1.6- \\
2.6) \\
\end{array}$ \\
\hline $\begin{array}{c}\text { Bay of Bengal } \\
(\text { Bangladesh })^{(17)}\end{array}$ & Sediment & $18-101$ & - & $138-1318$ & - \\
\hline $\begin{array}{c}\text { Jessore (Bangladesh) } \\
\text { [Present study] }\end{array}$ & Sediment & $\begin{array}{c}43 \\
(23-62)\end{array}$ & $\begin{array}{c}48 \\
(20-85)\end{array}$ & $\begin{array}{c}503 \\
(254-986)\end{array}$ & - \\
\hline
\end{tabular}

Radium equivalent activity, $\mathbf{R a}_{\mathrm{eq}}$

Calculated data of $\mathrm{Ra}_{\mathrm{eq}}$ is presented in column 7 of Table 2 . The $\mathrm{Ra}_{\mathrm{eq}}$ for soil varied in the range $130 \pm 15-210 \pm 13 \mathrm{Bqkg}^{-1}$ with the average value of $161 \pm 20 \mathrm{Bqkg}^{-1}$ and that for sediment varied in the range $71 \pm 12-259 \pm 15$ with an average value of $150 \pm 37 \mathrm{Bqkg}^{-1}$. Those are far below the allowable limit $\left(370 \mathrm{Bqkg}^{-1}\right)$ as recommended by the IAEA ${ }^{(1,2,4)}$.

\section{The absorbed dose rate}

In the present study the dose rate due to ${ }^{226} \mathrm{Ra},{ }^{232} \mathrm{Th}$, and ${ }^{40} \mathrm{~K}$ in soil samples varied from $62 \pm 7$ to $100 \pm 6 \mathrm{nGyh}^{-1}$ with an average of $77 \pm 9 \mathrm{nGyh}^{-1}$ and that for sediment varied from $34 \pm 6$ to $125 \pm 7$ with an average value of $72 \pm 18 \mathrm{nGyh}^{-1}$. Those are comparable with the world average value of $55 \mathrm{nGyh}^{-1(4)}$. 


\section{External and Internal Hazard Index}

The external hazard index $\left(\mathrm{H}_{\mathrm{ex}}\right)$ due to natural gamma radiation was calculated using the eq.(4) and the values are shown in column 9 of Table 2. The $\mathrm{H}_{\mathrm{ex}}$ value for soil in the study area ranged from $0.35 \pm 0.04$ to $0.57 \pm 0.03$ with the average value of $0.44 \pm 0.05$, and that for sediment ranged from $0.19 \pm 0.03$ to $0.70 \pm 0.04$ with the average value of $0.4 \pm 0.1$. The calculated $H_{e x}$ values for all samples should be lower than unity, which do not cause any harm to the population in all regions under investigation. All values of $\mathrm{H}_{\mathrm{ex}}$ in the present work are less than unity.

There is also a radiation hazard threat to respiratory organs due to the ${ }^{222} \mathrm{Rn}$, decay product of ${ }^{226} \mathrm{Ra}$, and its short-lived decay products. To account for this the maximum permissible concentration for radium must be reduced to half of the normal limit ${ }^{(2)}$. Considering this limit, the internal hazard index, $\mathrm{H}_{\text {in }}$ was calculated and is shown in the last column of Table 2. The $\mathrm{H}_{\text {in }}$ for soil is found to range from $0.43 \pm 0.04$ to $0.75 \pm 0.04$ with the average value of $0.57 \pm 0.07$ and for sediment it was found to range from $0.25 \pm 0.04$ to $0.86 \pm 0.05$ with the average value of $0.52 \pm 0.13$.

Table. 4.

Comparison of absorbed dose rate at one meter above the ground surface obtained in our study with that of others of the world

\begin{tabular}{|c|c|c|c|c|c|}
\hline Country & Year & $\begin{array}{c}\text { No of } \\
\text { samples }\end{array}$ & $\begin{array}{c}\text { Absorbed } \\
\text { dose rate in } \\
\text { nGyh }\end{array}$ & $\begin{array}{l}\text { Range } \\
\mathrm{nGyh}^{-1} \\
\end{array}$ & Method of analysis \\
\hline China $^{(4)}$ & 1972 & 26 & 69 & - & $\begin{array}{l}\text { Analysis of soil using } \\
\text { gamma spectrometry }\end{array}$ \\
\hline Romania $^{(4)}$ & 1979 & 2372 & 81 & $32-210$ & $\begin{array}{l}\text { Analysis of soil using } \\
\text { gamma spectrometry }\end{array}$ \\
\hline Nigeria ${ }^{(18)}$ & 2000 & 20 & 128 & $5-186$ & $\begin{array}{l}\text { Analysis of rocks } \\
\text { using gamma } \\
\text { spectrometry }\end{array}$ \\
\hline $\begin{array}{c}\text { Bangladesh } \\
\text { (six districts) }^{(19)}\end{array}$ & 2003 & 13 & 77 & $59-103$ & $\begin{array}{l}\text { Analysis of soil using } \\
\text { gamma spectrometry }\end{array}$ \\
\hline $\begin{array}{c}\text { Chittagong } \\
\text { (Bangladesh) }\end{array}$ & 1999 & 24 & 75 & $42-120$ & $\begin{array}{l}\text { Analysis of soil using } \\
\text { gamma spectrometry }\end{array}$ \\
\hline $\begin{array}{r}\text { India } \\
(\text { Kotagiri })^{(20)}\end{array}$ & 2002 & 39 & 95.2 & - & $\begin{array}{l}\text { Analysis of soil using } \\
\text { gamma spectrometry }\end{array}$ \\
\hline $\begin{array}{c}\text { World average }{ }^{(4)} \\
\text { Jessore, } \\
\text { Bangladesh } \\
\text { (Present study) }\end{array}$ & 2007 & 23 & $\begin{array}{l}55 \\
77\end{array}$ & $\begin{array}{c}30-70 \\
62-100\end{array}$ & $\begin{array}{l}\text { Analysis of soil using } \\
\text { gamma spectrometry }\end{array}$ \\
\hline
\end{tabular}

Table 3 and Table 4 show the comparative study of the present work with others of the world. However, slight variation in the radioactivity content in soil and sediment may be observed with different locations worldwide mainly due to soil type, formation and transport process involved. This may be the reason for the variation observed in our results as compared to those of others.

\section{ACKNOWLEDGEMENT}

The authors would like to thank the Health Physics Division of Bangladesh Atomic Energy Center (BAEC), Dhaka for allowing the experiment to be conducted in their 
laboratories; and the University Grants Commission, Bangladesh for the financial assistance in collecting the samples and carrying out the research project. Thanks are also due to Md. Ashraful Haque for his supports during works in the laboratories.

\section{REFERENCES}

1. UNSCEAR, 1993, Exposure from natural sources of radiation, United Nations, New York.

2. Beretka J., \& Mathew P. J., "Natural radioactivity of Australian building materials, industrial waste and by-products", Health Physics, 48(1), 87-95, 1985.

3. Noordin I., Natural activities of ${ }^{238} \mathrm{U},{ }^{232} \mathrm{Th}$ and ${ }^{40} \mathrm{~K}$ in building materials, Journal of Environmental Radioactivity, 43, 255-258(1999).

4. United Nations Scientific Committee on the Effect of Atomic Radiation UNSCEAR, Exposure from natural sources of radiation. Report to the General Assembly, UN, New York, USA(1988).

5. Delaune R.D., Jones G .L . \& Smith C . J., "Radionuclide Concentration in Louisiana Soils and Sediments", Health Physics, 51, 239-244(1986).

6. Chowdhury M. I., Alam M. N., Hazari S. K. S., Distribution of radionuclides in the river sediments and coastal soils of Chittagong, Bangladesh and evaluation of the radiation hazard, Applied Radiation and Isotope, 51(1999)747-755.

7. Roy S., Hoque A. \& Begum M., "Distribution of ${ }^{137}$ Cs and Naturally Occurring Radionuclides in Soil at Sites of the Roopur Nuclear Power plant", Nuclear Science and Applications. 10(1,2), 33-38, December 2001.

8. Miah F. K., Roy S., Touhiduzzaman M . \& Alam B ., "Distribution of Radionuclides in soil samples in and arround Dhaka city", App. Radiat.Isot, 49(1,2), 133-137(1998).

9. Chowdhury M.I., Kamal M., Alam M.N., Yeasmin Saleha and Mostafa M.N., Distribution of naturally occurring radionuclides in soils of the southern districts of Bangladesh. Radiation Protection Dosimetry(2006), 118(1)126-130.

10. Ali S., Tufail M., Jamie K., Ahmed A. \& Khan H. A., "Gamma-ray activity and dose rate of brick samples from some areas of North West Frontier Province(NWFP), Pakistan”, Science of total Environment, 187, 247-252(1996)

11. Prasad N.G. Shiva, Nagaiah N., Ashok G.V. and Karunakara N., Concentrations of ${ }^{226}$ Ra, ${ }^{232} \mathrm{Th}$ and ${ }^{40} \mathrm{~K}$ in the soils of Bangalore region, India, Health Physics, 94(3) 264-271(2008).

12. Bikit I., Verga E., Conkic Lj.et al , "Radioactivity of the Bega sediment - case study of a contaminated cannel", Applied Radiation and Isotopes 63(2005) 261-266.

13. Verga E., Bikit I., Slivka J. et al, 2003, Danube sediment radioactivity investigation. Proceedings of the Sixth International Symposium \& Exhibition on Environmental

14. Ibrahiem N.M., Shawky, S.M., Amer, H.A.,1995, "Radioactivity levels in Lake Nasser sediments." Applied Radiation and Isotopes 46(5)297-299.

15. Nina D., Drndarski and Natan Lavi, 1996, Radioactivity in sediments from the Grliska impoundment, Water Research, 30(6)1539-1542.

16. Lambrechts A., Foulquier L., Garnier-Laplace J., 1992, Natural radioactivity in the aquatic components of the main French rivers. Radiat. prot. Dosim. 45(1)253-256.

17. Sharif A.K.M., Bilkis A.B., Roy S., Sikder M.D.H., Idriss Ali K.M. \& Safiullah S. : Concentrations of radionuclides in coastal sediments from the Bay of Bengal, Sci. Tot. Environ., 158(1994)1-8. 
18. Ajayi O.S., "Distribution of Natural radioactivity in rocks from Ikogoshi-Ekiti, southwestern Nigeria and its radiological implications", Health Phys., 79(2), 192-195, 2000.

19. Rahman M. M., Rahman Rubina and Begum M., "Distribution of Natural and Artificial Radioactivity in Soil from Different District of Bangladesh", J. Bangladesh Acad. Sci., 22(2), 255-262, 1998

20. Selvasekarapandian S., Manikandan N.M., Sivakumar R. et al, Natural radiation distribution of soil at Katagiri Taluk of the Nilgiris biosphere in India, J. Radioanal. Nucl. Chem., $252(2002) 74-78$.

Journal of Bangladesh Academy of Sciences, Vol. 33, No. 1, 117-130, 2009 